$\mathbb{P}$ periodica polytechnica

Chemical Engineering

$5 2 / 1 ( 2 0 0 8 ) \longdiv { 1 7 } 2 2$

doi: 10.3311/pp.ch.2008-1.04

web: http://www.pp.bme.hu/ch

(c) Periodica Polytechnica 2008

RESEARCH ARTICLE

\section{Difficulties and solutions for the assays of the key enzymes of a new enzymatic glycerol bioconversion}

\author{
Áron Németh / Andrea Balássy / Béla Sevella
}

Received 2007-10-13

\begin{abstract}
For years our research group has been working on developing a new enzymatic method for the bioconversion of glycerol (a byproduct of biodiesel production) to 1,3-propanediol (PD) and 1,3-dihydroxyacetone (DHA) simultaneously. Our bioconversion method applies three key enzymes in a membrane reactor with coenzyme regeneration: glycerol-dehydratase (GDHt) that produces 3-hydroxy-propionaldehyde (HPA) from glycerol; 1,3-propanediol-oxydoreductase (PDOR) that converts $\mathrm{HPA}$ into PD using $\mathrm{NADH}_{2}$, that is then reoxydized by glyceroldehydrogenase $(G D H)$ during glycerol-DHA conversion. From an economical point of view crude enzyme solutions of sonicated $K$. pneumoniae and $C$. butyricum cells were used. In such a crude enzyme solution it was impossible to determine the GDHt activity with the assays known from the literature, thus a new method for GDHt activity determination was developed based on the measurment of HPA (formed by GDHt) with tryptophan in acidic conditions. Furthermore Lin's assay for PDOR was also modified, and then successfully adapted to GDH as well. In both cases, $\mathrm{NADH}_{2}$ formation should be followed photometrically, but in crude enzyme solutions a lot of $\mathrm{NAD}^{+} / \mathrm{NADH}_{2}$ dependent side-reactions disturb the activity determinations. In our improved method, the absorbance change should be recorded without substrate addition until the absorbance becomes stable, then adding the actual substrate the changing readings should be recorded further.
\end{abstract}

\section{Keywords}

glycerol-dehydratase activity; $1 \cdot 3$-propanediol oxydoreductase assay $\cdot$ glycerol dehydrogenase

\section{Áron Németh}

\section{Andrea Balássy}

Department of Applied Biotechnology and Food Science, BME, Szt. Gellért tér 4 H-1111 Budapest, Hungary

\section{Béla Sevella}

Department of Applied Biotechnology and Food Science, BME, Szt. Gellért tér 4 H-1111 Budapest, Hungary

e-mail: bsevella@mail.bme.hu

\section{Introduction}

Since the '90s high efforts have been made for developing a biological way of the 1,3-propandiol (PD) production [1]. The driving force was that Shell Chemicals introduced a new PD based polimer onto the market called Corterra $(\mathbb{R}$ which has excellent properties such as good resilience, inherent stain resistance, low electrostatic generation etc. To produce larger amount of this polimer (Poli-Trimethylene-Terephtalate, PTT) an efficient synthetic technology for the PD production was developed using ethylene-oxide carboxylation with $\mathrm{CO}$ followed by hydrogenation under high pressure.

Degussa uses the classical synthetic process for PD with improved catalysts starting with the hydrolysis of acrolein followed by hydrogenation.

In 2004 Shell Chemicals launched a new PTT plant in Montreal of 94.000 t/yr capacity and a PD plant (Geismar, Luisiana, USA) to provide the raw material PD with a capacity of 73.000 $\mathrm{t} / \mathrm{yr}$.

In 2006 started the first bio-PD plant in Loudon (Tennessee, USA) owned by DuPont-Tate \& Lyle BioProducts LLC. Their technology is based upon a recombinant Esherichia coli fedbatch fermentation and they use bio-PD to their PTT polymer

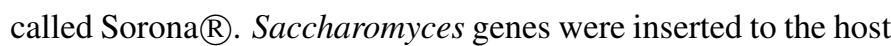
E.coli to convert glucose into glycerol, and then to PD using the dha regulon of Klebsiella pneumoniae.

Though the use of PD in polymers was the primary driving force to develop economic large scale technologies, PD can also be used for inks, refrigerants, and some of its derivatives can even be used as medicine to prevent the rejection of newly transplanted organs [2].

Although the only bio-based production of 1,3-PD is utilizing glucose, nowadays glycerol-based technologies become more advantageous, because of the accessibility of huge amounts of glycerol as reneweable byproduct from biodiesel production. Recognition of these facts forced our research group to develop a glycerol utilizing enzymatic bioconversion method.

Our proposed process uses three immobilized key enzymes in a membrane reactor with simultaneous coenzyme regeneration (Fig. 1): glycerol-dehydratase (GDHt, E.C. 4.2.1.30) pro- 
duces 3-hydroxy-propionaldehyde (HPA) from glycerol with or without $\mathrm{B}_{12}$ as coenzyme; 1,3-propanediol-oxydoreductase (PDOR, E.C. 1.1.1.202) converts HPA into PD using $\mathrm{NADH}_{2}$, which is then reoxydized by glycerol-dehydrogenase $(\mathrm{GDH}$, E.C. 1.1.1.6) during glycerol-DHA conversion.

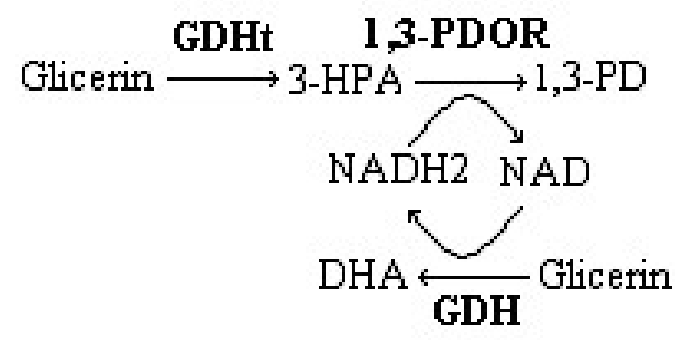

Fig. 1. Enzymatic bioconversion of glycerol to PD and DHA

As already published elsewhere [3] an enzyme fermentation method for the production of the necessary three key enzymes using Klebsiella pneumoniae was developed. The difficulties of simultaneous PD and DHA production with the enzymes of K.pneumoniae caused by the suicide inactivation and ATP depending regeneration of GDHt were also reported [4]. Since in the presence of ATP several byproducts can also be formed if crude enzyme solution is used, and GDHt regeneration also needs ATP, it is not possible to convert glycerol to 1,3-PD and DHA simultanously. To overcome this problem Clostridium butyricum was used as alternative enzyme source for its GDHt does not undergo suicide inactivation with glycerol and uses $S$ adenosine-methionine (SAM) instead of $\mathrm{B}_{12}$.

To collect data on the developing bioconversion reactions and for its mathematical description, as well as to determine the stability of the enzyme preparations it is necessary to determine the activity of the three key enzymes. There are two widely accepted methods in the literature [5, 6] but none of these were suitable for determining GDHt of Clostridium butyricum origin while the known assays for the other two enzymes were also possible to use only after some modifications of Lin's method [7].

\section{Materials and Methods}

K.pneumonaie and C.butyricum were cultured and enzyme solutions were obtained according to the methods published previously [3, 4].

\section{MBTH-method for GDHt determination [5]}

This method is based upon the ability of aldehydes to react with MBTH (3-methyl-2-benzothiazolinone hydrazone) forming an azine derivative which can be determined spectrophotometrically. The usual assay mixture contains an appropriate amount of diol dehydrase, $0.2 \mathrm{M}$ 1,2-propanediol, $0.05 \mathrm{M}$ $\mathrm{KCl}, 0.035 \mathrm{M}$ potassium phosphate buffer ( $\mathrm{pH} 8.0)$, and $15 \mu \mathrm{M}$ adenosyl cobalamin, in a total volume of $1.0 \mathrm{ml}$. After incubation at $37^{\circ} \mathrm{C}$ for $10 \mathrm{~min}$, the enzyme reaction is terminated by adding $1 \mathrm{ml} 0.1 \mathrm{M}$ potassium citrate buffer $(\mathrm{pH} 3.6)$ and 0.5 $\mathrm{ml}$ of $0.1 \% \mathrm{MBTH}$ hydrochloride. After $15 \mathrm{~min}$ incubation at $37^{\circ} \mathrm{C}, 1 \mathrm{ml}$ of water is added and the amount of propionaldehyde is determined from the absorbance at $305 \mathrm{~nm}$. The apparent molar extinction coefficient at $305 \mathrm{~nm}$ for the coloured product formed from propionaldehyde in the MBTH method is 13300 $\mathrm{M}^{-1} \mathrm{~cm}^{-1}$. One activity unit of GDHt is defined as the amount of enzyme catalyzing the formation of $1 \mu \mathrm{mol}$ of propionaldehyde in a minute under standard assay conditions. For routine assays, the amount of enzyme to be determined is kept between 0.003 and 0.03 units. In experiments in which more than 0.03 unit was used, the absorbance was measured after dilution.

\section{Coupled enzymatic method for GDHt determination [6]}

The activity of dioldehydratase was determined by a coupled reaction in which the propionaldehyde formed in the dioldehydratase reaction is reduced to 1-propanol in the presence of added alcohol-dehydrogenase (ADH) and excess $\beta$-NADH. The decrease of absorbance of NADH at $340 \mathrm{~nm}$ per unit time is the measure of the dioldehydrase activity. The usual assay mixture is composed of an appropriate amount of dioldehydrase, 0,2 M 1,2-propanediol, 38 $\mu \mathrm{g}$ (about 12 units) yeast alcoholdehydrogenase $(\mathrm{yADH}), 0,2 \mathrm{mM} \mathrm{NADH}, 0,04 \mathrm{M}$ potassium phosphate buffer $(\mathrm{pH}=8,0)$ and $10 \mu \mathrm{M}$ cobalamin coenzyme in an overall volume of $1 \mathrm{ml}$. The reaction is carried out at $37^{\circ} \mathrm{C}$ in a cuvette with $1 \mathrm{~cm}$ light path and started by adding coenzyme to the remainder of the reaction mixture which has been preincubated at $37^{\circ} \mathrm{C}$ for about $10 \mathrm{~min}$. One activity unit is defined as the amount of enzyme catalyzing the formation of $1 \mu \mathrm{mol}$ of propionaldehyde during one minute under the given standard conditions.

\section{Lin's method for PDOR determination [7]}

The activity of 1,3-propanediol oxidoreductase was determined spectrophotometrically $(\lambda=340 \mathrm{~nm})$ at $25^{\circ} \mathrm{C}$ by the initial rate of substrate-dependent NADH formation. The assay mixtures contained $100 \mathrm{mM}$ 1,3-propanediol, $0.6 \mathrm{mM} \mathrm{NAD}^{+}$, $30 \mathrm{mM}$ ammonium sulfate, and $100 \mathrm{mM}$ potassium bicarbonate buffer at $\mathrm{pH} 9.0$ in a 1-ml final volume. Units of activity are given in micromoles per minute at $25^{\circ} \mathrm{C}$.

$\mathrm{PD}, \mathrm{MBTH}$, yeast acohol-dehydrogenase, $\mathrm{B}_{12}$ were purchased from Sigma, and DHA from Merck. The other chemicals were obtained from Reanal Rt. (Hungary).

\section{Results and Discussion}

\subsection{Determining PDOR activity}

It can be seen in Fig. 2 that measuring PDOR activity in a crude enzyme solution of K.pneumoniae according to Lin's method resulted in high apparent enzyme activity even when there was no substrate in the reaction mixture. However, this absorbance increase (,activity”) slowed down gradually (Fig. 2). The reason of this phenomenon is that although the harvested cells were washed twice with HEPES buffer [4], there were still enough remaining glycerol in the enzyme solution, and at the same time the crude enzyme ,soup” contained also GDH (which 
is active on glycerol when $\mathrm{NAD}^{+}$is present), and this enzyme produced $\mathrm{NADH}_{2}$, thus the absorbance was rising without added PD.

When the residual glycerol runs out, the absorbance change stops, and with added 1,3-PD a linear absorbance change can be detected (after a dilution caused quick drop).

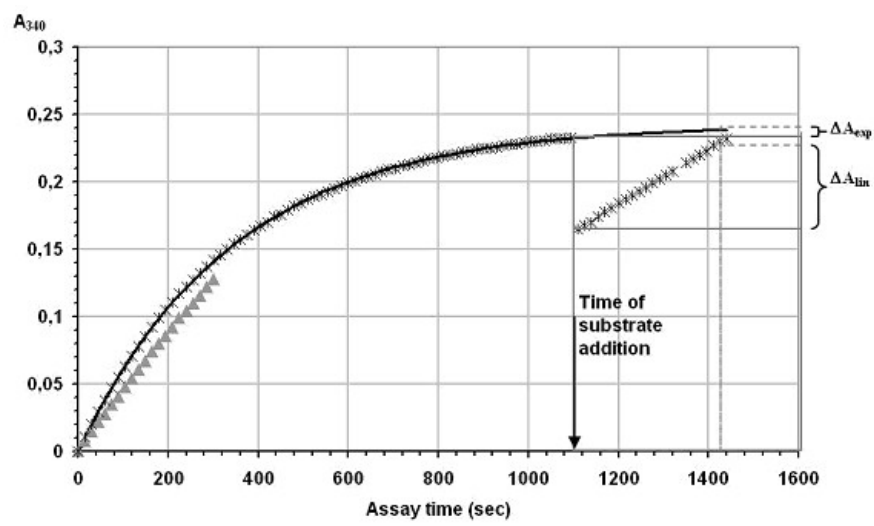

Fig. 2. Methods for PDOR activity $\triangle$ Lin's method (PD at start point), $\mathbf{X}$ water instead of PD at start, and later added PD - fitted exponential curve and extrapolation

In order to shorten this background reaction during the assay, it is suggested to drive the enzyme producing bacterial fermentation as far as possible to reduce the residual glycerol, and to wash the collected cells twice with buffer of the same amount as the volume of the cell suspension.

To overcome the problem above, modification of the Lin's method was necessary. First the whole reaction mixture (700 $\mu 1$ enzyme solution after appropriate dilution with $100 \mu \mathrm{l}$ buffer ( $1 \mathrm{M}$ containing $\left.0,3 \mathrm{M}\left(\mathrm{NH}_{4}\right)_{2} \mathrm{SO}_{4}\right)$ and $100 \mu \mathrm{NAD}^{+}$solution $(0,1 \mathrm{M}))$ should be incubated for 8 minutes, and if the absorbance change slows down or stops, $100 \mu 1$ substrate 1,3-PD (1 M) can be added and the absorbance change have to be followed for further 7 minutes. The PD addition causes a little drop in the absorbance, but after that, linear change can be obtained according to the use of excess coenzyme and substrate (Fig. 2 linear part). If the ,background reaction” totally stopped after the first $8 \mathrm{~min}$, the activity was determined only from the second (linear) part of the graph using the Lambert-Beer law $\left(\varepsilon_{N A D H}=6220 \mathrm{M}^{-1} \mathrm{~cm}^{-1}=6,22 \mathrm{ml} \cdot \mu \mathrm{mol}^{-1} \cdot \mathrm{cm}^{-1}\right.$ [8]. If the background reactions were only slowed down but not ended, an exponential curve was fitted (using SigmaPlot 7 software) to the first part of the curve, and it was extended to the second part to determine the absorbance changes caused by the background. The total absorbance difference of the linear phase was corrected (lowered) with the absorbance difference of the mathematically extended background reaction according to Eq. 1 .

$$
\text { Enzyme activity }\left[\frac{\mathrm{U}}{\mathrm{ml}}=\frac{\mu \mathrm{mol}}{\mathrm{min} \cdot \mathrm{ml}}\right]=\frac{\frac{\Delta \mathrm{A}_{\mathrm{lin}}-\Delta \mathrm{A}_{\mathrm{exp}}}{\Delta \mathrm{t}[\mathrm{sec}]} \cdot 60}{6.220\left[\frac{1}{\frac{\mu \mathrm{mol}}{\mathrm{ml}} \cdot \mathrm{cm}}\right]}
$$

To test this new method, we described the reactions with a mathematical model. Simulations were performed on the basis of two-enzyme reactions of bisubstrate kinetics of random bi-bi mechanism fitted to the measured data (Fig. 3.a). It was also examined whether the length of assay and the length of background exponential curve have effect on the measured activity value or not. In (Fig. 3.b) it can be seen, that choosing a suitable time length for the assay $(0,6 \mathrm{~h}$ in this case) and for the background reactions $(0,375 \mathrm{~h})$ the standard deviation decreased to an acceptable low level.

This method was adopted also for measuring the GDH activity.

(g/L)

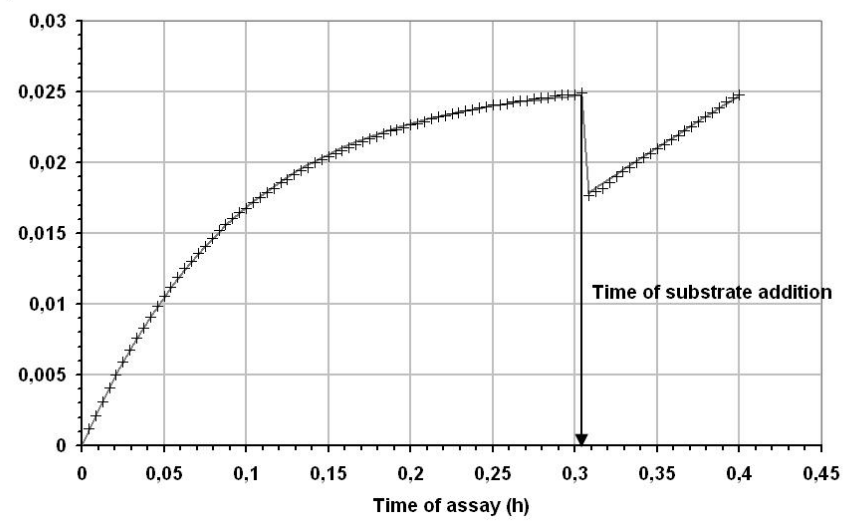

Fig. 3.a. + measured and - simulated $\mathrm{NADH}_{2}$ concentration change during PDOR activity measure

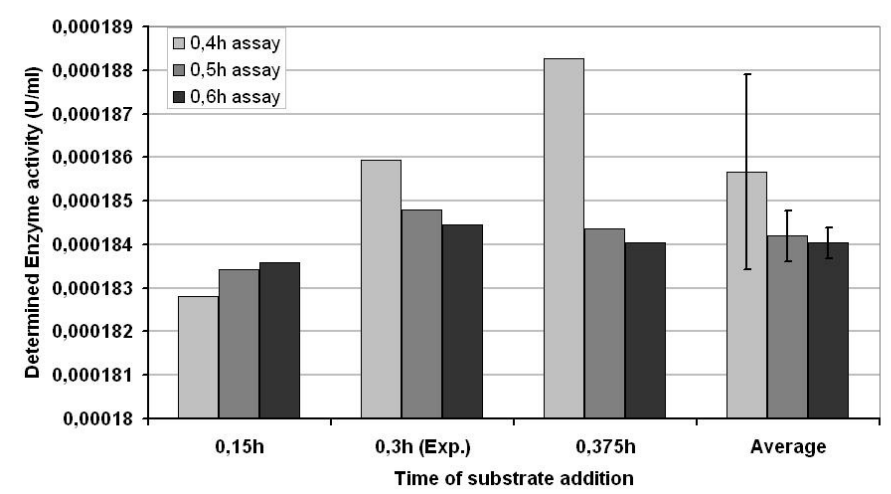

Fig. 3.b. The effect of substrate addition time and assay length on the measured PDOR activity

Waiting until the background reactions stop, or slow down to a negligible level was proven to be the most acceptable. The ratios between the length of the assay and the time of substrate addition are shown in Table 1.

The simulations results, where the standard deviations of the average were low (c.a. 0,1\%) are marked in Table 1 with greyish background. Regarding these, it can be decided to carry out assays with starting the substrate addition at the timepoint around $60 \%$ of the whole assay length.

A usual PDOR assay using Clostridium enzymes can be seen in Fig. 4 One can see that background seems to be stopped and is negligible thus there is no need to extrapolate. 
Tab. 1. The standard deviations of the determined activity depening on the length of the assay and the time of substrate addition

\begin{tabular}{|c|c|c|c|c|c|}
\hline \multirow{2}{*}{\multicolumn{2}{|c|}{ Activity $\times 10^{-4} \mathrm{U} / \mathrm{ml}$}} & \multicolumn{3}{|c|}{ Time of substrate addition (h) } & \multirow{2}{*}{$\begin{array}{l}\text { Std.Dev. } \\
\%\end{array}$} \\
\hline & & 0.150 & 0.300 & 0.375 & \\
\hline \multirow[t]{3}{*}{ Assay length (h) } & 0.4 & 1.8281 & 1.8593 & 1.8826 & 1.21 \\
\hline & 0.5 & 1.8342 & 1.8481 & 1.8436 & 0.31 \\
\hline & 0.6 & 1.8360 & 1.8446 & 1.8405 & 0.19 \\
\hline Std.Dev. & $\%$ & 0.18 & 0.34 & 1.04 & 0.1 \\
\hline
\end{tabular}

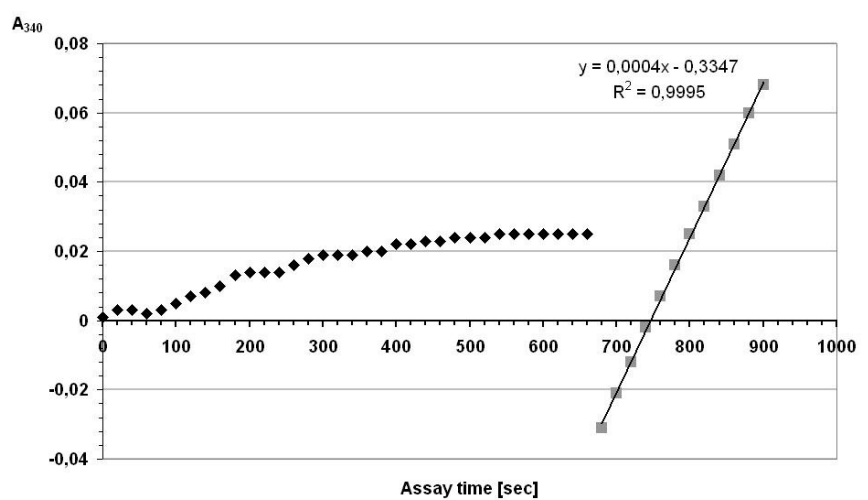

Fig. 4. Assay of PDOR from C. butyricum

\subsection{Determining GDHt activity}

Enzyme activity of K.pneumoniae origin could be properly determined by the MBTH method of [5] in the presence of 1,2propanediol substrate. Although [9] used this MBTH method with 1,2-propanediol for C. butyricum $\mathrm{GDHt}$ assay, when it was applied recently in authors' laboratory for the enzyme preaparation of C.butyricum, it resulted always in almost zero activity (i.e. little changes in the absorbance, Table 2 , column 1). Thus this method was inconvenient, either because there could not be detected any activity as a consequence of the dilution, or when using the crude enzyme solution without dilution a lot of protein was precipitated at the timepoint of terminating the reaction by potassium citrate buffer. On the other hand these enzyme solutions showed successful glycerol $\rightarrow$ 1,3-PD bioconversions, what contradicts to the measured low or none activity. On the bases of these experiences a modified approach to determine the GDHt activity with the MBTH method applying 2M glycerol substrate instead of $2 \mathrm{M} \mathrm{1,2-propanediol} \mathrm{(reversal} \mathrm{of} \mathrm{the} \mathrm{reac-}$ tion direction) resulted in that the absorbance (and consequently the calculable activity) seemed to be independent from the applied dilution (Table 2 , column 2. and 3). The used enzyme-free buffers showed also the same absorbance and „activity” as the real samples. If blank has been created not replacing glycerol substrate with water but adding glycerol and citrate at the start, then the absorbances were very low again (but blank has high absorbance, Table 2 column 4). This can only be happen, if glycerol also reacts with MBTH.

In the coupled method for GDHt determination, the HPA produced by the enzyme is reduced to the corresponding alcohol by yeast alcohol-dehydrogenase (yADH) meanwhile the added $\mathrm{NADH}_{2}$ is oxidized to $\mathrm{NAD}^{+}$resulting in linear decrease of the absorbance.
However, if this method was applied for Klebsiella enzyme solution, after an initial decrease of the absorbance, always a significant increase was observed. An acceptable explanation of this is that GDHt of Klebsiella pneumoniae undergoes suicide inactivation. While the GDHt concentration (and activity) decreases, the activity of GDH on 1,2-PD becomes to dominate in the presence of NAD (produced earlier by GDHt linked yADH) and produces $\mathrm{NADH}_{2}[10]$ resulting in an absorbance increase (Fig. 5).

In the case of Clostridium butyricum the observations were different: since the GDHt enzyme is not exposed to suicide inactivation, and the ratio of GDH to GDHt was originally very high in the crude enzyme solutions (GDHt was not detectable with MBTH on 1,2-PD), thus instead of a decrease in the absorbance, an increase was detected caused by GDH in the presence of $\mathrm{NAD}^{+}$(originally present in the crude enzyme solution) even when blank reaction mixture was prepared (Fig. 6.a) with neither 1,2PD nor glycerol addition. In real samples (Fig. 6.b. the result was the same as in the blanks, only the slope of the increase was lower, because GDHt-yADH system was active and consumed the $\mathrm{NADH}_{2}$ produced by GDH.

$\mathbf{A}_{340}$

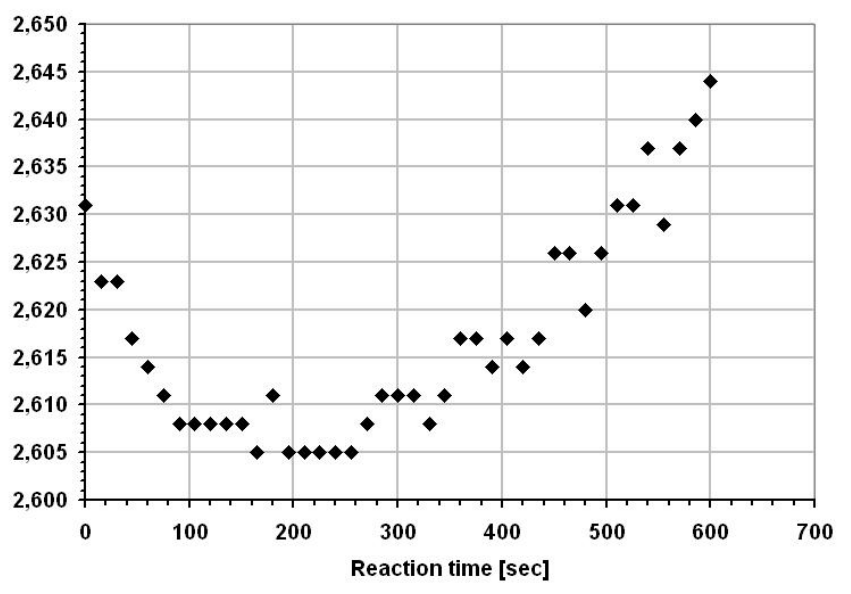

Fig. 5. yADH method for GDHt

As in enzyme assays substrates and coenzymes must be used in exess (at a saturation level) it is impossible to detect their consumption, so one have to measure the product formation. In our case this makes it necessary to measure HPA (produced from glycerol) with a suitable method.

[11] proposed an HPLC method to measure HPA but that would be disadvantageous here from practical point of view. Others (like [12]-[13]) used tryptophan in acidic conditions resulting in a measurable purple colour compound. Since 
Tab. 2. Determination of the GDHt activity with MBTH method

\begin{tabular}{|c|c|c|c|c|c|c|c|c|}
\hline \multirow{3}{*}{$\begin{array}{l}\text { Blank: } \\
\text { Substrate: }\end{array}$} & water & & \multicolumn{2}{|l|}{ water } & \multicolumn{2}{|l|}{ water } & \multicolumn{2}{|c|}{$\begin{array}{l}\text { glycerol+citrate } \\
\mathrm{A}_{305}=1.211 \text { against air }\end{array}$} \\
\hline & $2 \mathrm{M} 1.2 \mathrm{PD}$ & & $2 \mathrm{M}$ glycerol & & $2 \mathrm{M}$ glycerol & & $1 \mathrm{M}$ glyce & \\
\hline & Dilution & $\mathrm{A}_{305}$ & Dilution & $\mathrm{A}_{305}$ & Dilution & $\mathrm{A}_{305}$ & Dilution & $\mathrm{A}_{305}$ \\
\hline sample1 & $2.5 x$ & 0.006 & $2.5 x$ & 1.276 & $2 x$ & 1.176 & $1 \mathrm{x}$ & 0.062 \\
\hline sample2 & $2.5 x$ & 0.017 & $2.5 x$ & 1.276 & $5 x$ & 1.149 & $1 \mathrm{x}$ & 0.016 \\
\hline sample3 & $2.5 x$ & 0.008 & $2.5 x$ & 1.276 & $10 x$ & 1.024 & $1 \mathrm{x}$ & 0.02 \\
\hline HEPES buffer & & & & & $1 \mathrm{x}$ & 1.241 & & \\
\hline K-P buffer & & & & & $1 x$ & 1.211 & & \\
\hline
\end{tabular}

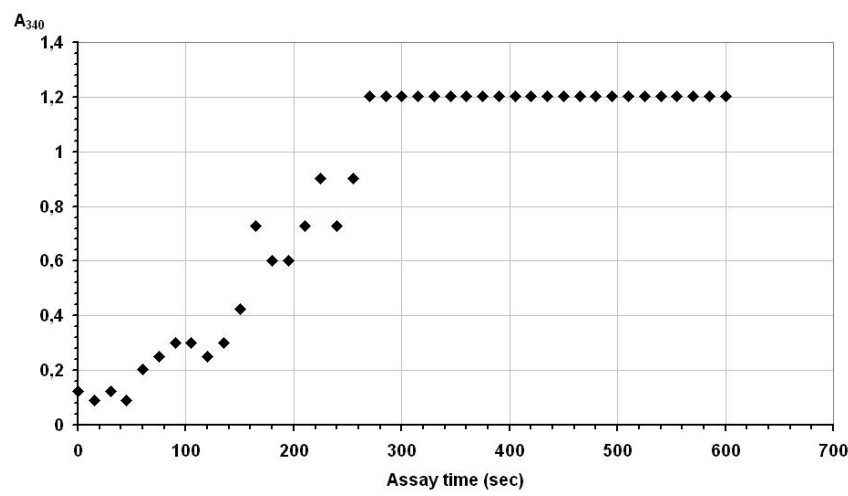

Fig. 6.a. Blank reaction for GDHt determination with $\mathrm{yADH}$

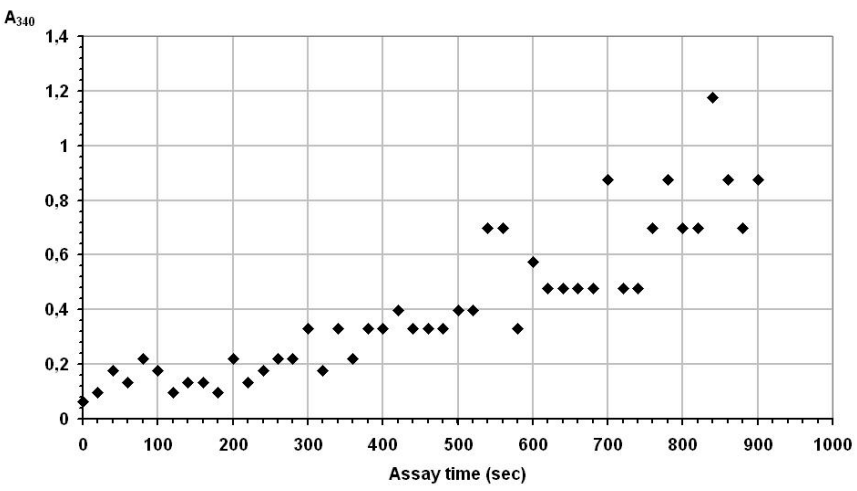

Fig. 6.b. A sample reaction for GDHt determination with yADH this method is suitable for the determination of enzymatically formed HPA this method was adopted when developing a new GDHt assay. As aldehydes can disturb this reaction, a blank reaction should also be prepared containing the enzyme solution in the same dilution and water instead of glycerol substrate.

The developed new GDHt assay is as follows: In a test tube ( $5 \mathrm{ml}$ total volume) the appropriate diluted enzyme solution $(0,7 \mathrm{ml})$ has to be preincubated for $10 \mathrm{~min}$ on $37^{\circ} \mathrm{C}$ with $0,1 \mathrm{ml}$ $0,4 \mathrm{M}$ potassium phosphate buffer $(\mathrm{pH}=8,[5])$ and with either $0,1 \mathrm{ml} \mathrm{B} 12$ coenzyme solution (in Klebsiella case) or with distilled water (in Clostridium case). Then addition of $0,1 \mathrm{ml} 1 \mathrm{M}$ glycerol as substrate (or $0,1 \mathrm{ml}$ distilled water when preparing blank) starts the enzyme reaction that is followed by a further $15 \mathrm{~min}$ incubation. After the incubation $3 \mathrm{ml}$ concentrated $\mathrm{HCl}$ is added to terminate the reaction. Addition of $0,75 \mathrm{ml}$ tryptohpan solution $(10 \mathrm{mM}$ tryptophan in $0,05 \mathrm{~N} \mathrm{HCl})$ and subsequent incubation for $40 \mathrm{~min}$ on $37^{\circ} \mathrm{C}$ follows. The intensity of the purple colour can then be measured photometrically at $560 \mathrm{~nm}$ against blank.

In this case even the very small amount of $\mathrm{NADH}_{2}$ present in the crude enzyme solution causes also difficulties, because PDOR can consume HPA with the help of $\mathrm{NADH}_{2}$, thus no product of GDHt reaction can be measured. This problem can be solved by washing out the $\mathrm{NADH}_{2}$ coenzyme from the enzyme solution with either HEPES or potassium-phosphate buffer through a 10kDa ultrafilter membrane (either in Millipore Stirred Cell, or in Amicon Centrifugal Ultrafiltration Unit). A concentration for at least one sixth of the original volume of enzyme solution followed by redilution to the original volume is a suitable method to remove $\mathrm{NADH}_{2}$ coenzyme. By this modification the method is suitable for the HPA product determination as Table 3 proves.

\section{Conclusion}

When developing a new production technology economical feasibility is always a crucial point of view. In our researches we intended to develop a new enzymatic method for simultaneous 1,3-propanediol and 1,3-dihydroxyacetone production in a membrane reactor. To reach a cost effective process application of non purified crude enzyme solutions of disrupted $K$. pnaumoniae and C.butyricum cells was to be applied. Since the measurements of the enzyme activities in such crude en- 
Tab. 3. GHDt activity measuremets results with tryptophan method

\begin{tabular}{lllll}
\hline & \multicolumn{2}{c}{ Without washing } & \multicolumn{2}{c}{ With washing } \\
\hline & Dilution & $\mathrm{A}_{560}$ & Dilution & $\mathrm{A}_{560}$ \\
Blank & $2 \mathrm{x}$ & 0.000 & $2 \mathrm{x}$ & 0.000 \\
Sample1 & $2 \mathrm{x}$ & 0.007 & $2 \mathrm{x}$ & 0.078 \\
Sample2 & $2 \mathrm{x}$ & 0.024 & $2 \mathrm{x}$ & 0.082 \\
Sample3 & $2 \mathrm{x}$ & -0.011 & $2 \mathrm{x}$ & 0.086 \\
\hline Average: & & 0.007 & & 0.082 \\
Std.dev. & & 0.014 & & 0.003 \\
\hline
\end{tabular}

zyme preparations were impossible by the usual enzyme assays known from the literature, the proposed assay methods for all key enzymes have been thoroughly investigated, and for glycerol-dehydratase, for 1,3-propanediol-oxydoreductase and for glycerol dehydrogenase new or improved methods have been developed.

Lin's method for PDOR assay showed an apparent activity even without substrate, because of the presence of GDH and residual glycerol from fermentation broth. To avoid this, Lin's method was modified. It is recommended to record the changes in the absorbance firstly without substrate, and after the absorbance becomes stable, substrate can be added, and absorbance should be measured continuously.

The MBTH method of Toraya for GDHt assay uses 1,2-PD as substrate, but our enzyme preparation had too little activity on 1,2-PD but good activity on glycerol. However, not only the HPA product but also glycerol seemed to react with MBTH. The coupled enzymatic method using ADH was also not suitable, because in the assay the $\mathrm{ADH}$ produced $\mathrm{NAD}^{+}$from the added $\mathrm{NADH}_{2}$ and that was re-reduced again by GDH to $\mathrm{NADH}_{2}$.

To overcome these problems a new colourimetric method for GDHt was developed by measuring the reaction product HPA with tryptophan in acidic conditions.

\section{References}

1 Biebl H, Menzel K, Zeng AP, Deckwer WD, Microbial production of 1,3propanediol, Appl. Microbiol. Biotechnol 52 (1999), 289-297.

2 Robert $\mathbf{P}$, Wenger R, Cottens $\mathbf{S}$, Use for 1,3-propanediol derivatives to prevent rejection after organ transplantation (1999). patent WO 9822100.

3 Németh Á, Kupcsulik B, Sevella B, 1,3-Propanediol oxidoreductase production with Klebsiella pneumoniae DSM2026, World J. Microbiol. Biotechnol. 19 (2003), no. 7, 659-663.

4 Németh Á, Sevella B, Development of a New Bioprocess for Production of 1,3-propanediol I.: Modeling of Glycerol Bioconversion to 1,3-propanediol with Klebsiella pneumoniae Enzymes, Appl. Biochem. Biotechnol. (2007). DOI: 10.1007/s12010-007-0040-5.

5 Toraya T, Ushio K, Fuki S, Hogenkamp H P C, Studies on the Mechanism of the Adenosylcobalamin-dependent Diol Dehydrase Reaction by the Use of Analogs of Coenzyme, J. biol. chem. 252/3 (1977), 963-970.

6 Toraya T, Krodel E, Mildvan AS, Abeles RH, Role of peripheral side chains of vitamin $B 12$ coenzymes in the reaction catalyzed by dioldehydrase, Biochem. 18/3 (1979), 417-26.

7 Johnson EA, Lin ECC, Klebsiella pneumoniae 1,3-propanediol $\mathrm{NAD}^{+}$. oxidoreductase, Bacteriol, J 169 (1987), 2050-2054.

8 Obon JM, Manjon A, Iborra JL, Retention and regeneration of native $N A D(H)$ in noncharged ultrafiltration membrane reactors: application to $L$ - lactate and gluconate production, Biotechnol Bioeng 57 (1998), no. 5, 510516.

9 Raynaud C, Sarçabal P, Meynial-Salles I, Croux C, Soucaille P, Molecular characterization of the 1,3-propanediol operon of Clostridium butyricum encoding a novel coenzyme B12 independent glycerol dehydratase and a 1,3 propanediol dehydrogenasen, Proc. Natl. Acad. Sci. USA, 2003, pp. 50105015.

10 available at www. brenda. uni-koeln. de

11 Talarico TL, Casas IA, Chung TC, Dobrogosz WJ, Production and isolation of reuterin, a growth inhibitor produced by Lactobacillus reuteri, Antimicrob Agents Chemother 32/12 (1988), 1854-1861.

12 Luthi-Peng Q, Scharer S, Puhan Z, Production and stability of 3hydroxypropionaldehyde in Lactobacillus reuteri, Appl Microbiol Biotechnol 60 (2002), no. 1-2, 73-80.

13 Sidney J, Circle LS, Boruff CS, Acrolein determination by means of tryptophane, Ind. Eng. Chem. 17 (1945), no. 4, 259-262. 